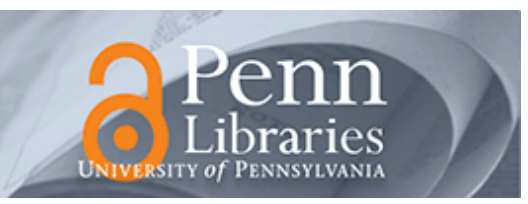

University of Pennsylvania

ScholarlyCommons

Departmental Papers (EES)

September 2006

\title{
Modern saltmarsh diatom distributions of the Outer Banks, North Carolina, and the development of a transfer function for high resolution reconstructions of sea level
}

\author{
Benjamin P. Horton \\ University of Pennsylvania, bphorton@sas.upenn.edu \\ Reide Corbett \\ East Carolina University \\ Stephen J. Culver \\ East Carolina University \\ Robin J. Edwards \\ Trinity College Dublin \\ Caroline Hillier \\ University of Durham
}

Follow this and additional works at: https://repository.upenn.edu/ees_papers

\section{Recommended Citation}

Horton, B. P., Corbett, R., Culver, S. J., Edwards, R. J., \& Hillier, C. (2006). Modern saltmarsh diatom distributions of the Outer Banks, North Carolina, and the development of a transfer function for high resolution reconstructions of sea level . Retrieved from https://repository.upenn.edu/ees_papers/46

Postprint version. Published in Estuarine, Coastal and Shelf Science, Volume 69, Issues 3-4, September 2006, pages 381-394.

Publisher URL: http://dx.doi.org/10.1016/j.ecss.2006.05.007

This paper is posted at ScholarlyCommons. https://repository.upenn.edu/ees_papers/46

For more information, please contact repository@pobox.upenn.edu. 


\title{
Modern saltmarsh diatom distributions of the Outer Banks, North Carolina, and the development of a transfer function for high resolution reconstructions of sea level
}

\author{
Abstract \\ We collected modern diatom samples from Currituck Barrier Island, Oregon Inlet and Pea Island marshes, \\ Outer Banks, North Carolina, USA, which have different salinity regimes due to their varying distances \\ from a major barrier island inlet. Multivariate analyses separate the saltmarsh diatom assemblages into \\ distinct elevational zones, dominated by differing abundances of polyhalobous, mesohalobous and \\ oligohalobous taxa, suggesting that the distribution of saltmarsh diatoms is a direct function of elevation, \\ with the most important controlling factors being the duration and frequency of subaerial exposure. \\ We developed the first diatom-based transfer function for the east coast of North America to reconstruct \\ former sea levels based upon the relationship between diatom assemblage and elevation. Results imply \\ that this is possible to a precision of $\pm 0.08 \mathrm{~m}$, superior to most similar studies from temperate, mid- \\ latitude environments. The transfer function is used to construct a relative sea-level curve from fossil \\ assemblages from Salvo, North Carolina. These results suggest a sea-level rise of $0.7 \mathrm{~m}$ over the last c. \\ 150 years, at an average of c. $3.7 \mathrm{~mm}$ year $^{-1}$. This is consistent with existing sea-level data, and \\ illustrates the utility of the transfer function approach.

\section{Keywords} \\ salt marshes, sea level changes, diatoms, lead-210, radiometric dating, transfer functions, North Carolina

\section{Comments} \\ Postprint version. Published in Estuarine, Coastal and Shelf Science, Volume 69, Issues 3-4, September \\ 2006, pages 381-394. \\ Publisher URL: http://dx.doi.org/10.1016/j.ecss.2006.05.007
}




\section{Modern saltmarsh diatom distributions of the Outer Banks,}

North Carolina, and the development of a transfer function for high resolution reconstructions of sea level

Benjamin. P. Horton ${ }^{\mathrm{a}}{ }^{*}$, Reide Corbett ${ }^{\mathrm{b}}$, Stephen J. Culver ${ }^{\mathrm{b}}$, Robin J. Edwards ${ }^{\mathrm{c}}$ and Caroline Hillier ${ }^{\mathrm{d}}$.

${ }^{\text {a }}$ Sea Level Research Laboratory, Department of Earth and Environmental Science, University of Pennsylvania, Philadelphia, PA 19104-6316, USA.

${ }^{\mathrm{b}}$ Department of Geology, East Carolina University, Greenville, North Carolina 27858, USA.

${ }^{\mathrm{c}}$ Departments of Geography and Geology, Trinity College Dublin, Dublin 2, Ireland.

${ }^{\mathrm{d}}$ Department of Geography, University of Durham, Durham, DH1 3LE, UK

* Corresponding author. Sea Level Research Laboratory, Department of Earth and Environmental Science, University of Pennsylvania, Philadelphia, PA 19104-6316, USA. Tel: 215573 5388; Fax: 215898 0964; E-mail: bphorton@sas.upenn.edu. 


\begin{abstract}
We collected modern diatom samples from Currituck Barrier Island, Oregon Inlet and Pea Island marshes, Outer Banks, North Carolina, USA, which have different salinity regimes due to their varying distances from a major barrier island inlet. Multivariate analyses separate the saltmarsh diatom assemblages into distinct elevational zones, dominated by differing abundances of polyhalobous, mesohalobous and oligohalobous taxa, suggesting that the distribution of saltmarsh diatoms is a direct function of elevation, with the most important controlling factors being the duration and frequency of subaerial exposure.
\end{abstract}

We developed the first diatom-based transfer function for the east coast of North America to reconstruct former sea levels based upon the relationship between diatom assemblage and elevation. Results imply that this is possible to a precision of $\pm 0.08 \mathrm{~m}$, superior to most similar studies from temperate, mid-latitude environments. The transfer function is used to construct a relative sea-level curve from fossil assemblages from Salvo, North Carolina. These results suggest a sea-level rise of $0.7 \mathrm{~m}$ sea-level rise over the last c. 150 years, at an average of c. $3.7 \mathrm{~mm} \mathrm{yr}^{-1}$. This is consistent with existing sea-level data, and illustrates the utility of the transfer function approach.

Keywords: Salt marshes; Sea level changes; Diatoms; Lead 210; Radiometric dating; Transfer functions; North Carolina 


\section{Introduction}

Diatoms are unicellular algae with chrysophyte-like photosynthetic pigments. The cell wall is silicified to form a frustule, comprising two valves. Diatoms have been recorded and classified for over 200 years. In the late 1890s the systematic and taxonomic investigations of modern and fossil diatoms began to be supported by studies of distributional ecology (e.g. Cleve, 1894-1895). However, it was not until the 1920s that diatom analysis was recognized as a valuable tool in reconstructing ecological changes (e.g. Cleve-Euler, 1922; Hendey, 1964; Patrick and Reimer, 1966-1975; Cooper and Brush, 1991; Denys, 1991/1992; Vos and de Wolf, 1993; Hartley, 1996; Cooper, 1999).

The study of the ecology of contemporary diatom distributions has shown salinity to be the dominant control (Hendey, 1964). Accordingly many species have been classified based upon their salinity (halobian) preference (van der Werff and Huls, 1958-1966; Hudstedt, 1953, 1957). Polyhalobous species thrive in fully marine conditions, with a salinity exceeding 30 practical salinity units (psu). Mesohalobous diatoms thrive in salt concentrations of between 0.2 psu and 30 psu. Oligohalobous diatoms generally occur in salt concentrations less than 0.2 psu. Vos and de Wolf (1993) and Juggins (1992) further divided the latter category into oligohalobous-halophilus, which have an optimum in weakly brackish waters, and oligohalobous-indifferent, which show a preference for fresh water, but are tolerant of slightly brackish conditions. Halophobous diatoms are highly intolerant of salt and are found exclusively in fresh water. Vos and de Wolf (1993) also coded diatoms based upon life form (planktic, benthic and epiphytic), substrate preference, $\mathrm{pH}$, nutrient content and temperature. Many of these factors are directly related to elevation with respect to the tidal range.

In coastal sediments, diatoms are used to record environmental changes in salinity (e.g. Juggins, 1992) and subaerial exposure (e.g. Hemphill-Haley, 1995a). Round (1991) stated that diatoms preserved in sediments from continental margins will reveal a complex history of sea-level changes. 
However, the established reconstruction of coastal history based on diatom biostratigraphical techniques (e.g. Zong and Tooley, 1996) relies strongly on the simple classifications of taxa into freshwater, brackish or marine forms, and provide only qualitative estimates of ecological conditions. Given this general paucity of information, ecologists have recently adopted a quantitative approach to ecological reconstruction (e.g. Imbrie and Kipp, 1971; Nelson and Kashima, 1993; Hemphill-Haley, 1995a, b, c; Jones and Juggins, 1995; Wilson, et al., 1995; Gasse et al., 1997; Sherrod, 1999; Zong et al., 2001; Sawai, et al., 2004a, b). In coastal studies, the transfer function approach is producing a new generation of high-resolution sea-level reconstructions that is seeking to bridge the gap between shortterm instrumental records and long-term, traditional geological reconstructions or geophysical predictions (e.g. Zong and Horton, 1998, 1999; Horton et al., 1999, 2000, 2003; Gehrels, 2000; Edwards and Horton, 2001, in press; Gehrels et al., 2001, 2002; Edwards et al., 2004a, b; Horton and Edwards, 2005, in press).

Studies of diatoms and their relationship to relative sea level in coastal and estuarine environments from the east coast of North America, however, are sparse (e.g. Kapruan, 1980; Laird and Edgar, 1992; Cooper and Brush, 1991, 1993; Cooper, 1995). Thus in this paper we present diatom distribution data from three back-barrier study sites from the Outer Banks, North Carolina, USA (Currituck Barrier Island, Oregon Inlet and Pea Island). Furthermore, we develop the first diatombased transfer function to reconstruct former sea-levels from passive coastal margins in North America. The transfer function is applied to fossil assemblages from Salvo, North Carolina to derive quantitative estimates of former sea-levels.

\section{Study sites}

We have selected three study sites, Currituck Barrier Island, Oregon Inlet and Pea Island marshes, Outer Banks, North Carolina, USA (Figure 1). These sites have different salinity regimes due to their 
varying distances from a major barrier island inlet. The tidal conditions of the Outer Banks are unique; the astronomical tidal range is small (e.g. diurnal range of $0.36 \mathrm{~m}$ at Oregon Inlet) but with significant, very variable and rapidly changing wind tides from less than $30 \mathrm{~cm}$ to more than $3 \mathrm{~m}$ (during hurricanes) in amplitude (Riggs, 2002).

Currituck Barrier Island is the most northerly back-barrier site, with the greatest distance (56 km) from Oregon Inlet, a major inlet which has existed since 1846 AD. The salinity of open water at Currituck Sound is low (c. 5 psu) at the time of sample collection (August 2002). The marsh at this site is approximately $200 \mathrm{~m}$ in width and displays a succession from narrow tidal flat through Juncus roemerianus low marsh to a mixed Juncus roemerianus and Spartina cynusoroides high marsh. The porewater salinity values increase from the Sound ( $5 \mathrm{psu}$ ) to the marsh fringe to a maximum within the Spartina cynusoroides marsh community (12 psu). Salinity, subsequently, decreases to 6 at the landward end of the transect (Culver and Horton, 2005; Horton and Culver, in press). The pH values also show an increase from Currituck Sound (3.4) to the Spartina cynusoroides marsh community (6.2). The sediments coarsen landward, with a maximum clay fraction of 23\% within Currituck Sound and a minimum of $6 \%$ at the landward edge of transect. The loss on ignition (LOI) values and proportion of vegetation cover increases from the sound to the Spartina cynusoroides marsh community, with $100 \%$ vegetation cover reached $16 \mathrm{~m}$ along the transect.

The back-barrier marsh site at Oregon Inlet is less than $1 \mathrm{~km}$ from the waterway, which links Pamlico Sound to the Atlantic Ocean. The site thus displays similar salinities (c. 31 psu at time of sampling) to a normal marine environment. The marsh is approximately 200 m wide and covers a broad range of environments including, a narrow tidal flat and Spartina alterniflora and Juncus roemerianus marshes, with freshwater shrubs found at the landward edge of the transect. Porewater salinity values generally decrease from Pamlico Sound to the landward edge of the transect (Culver and Horton, 2005; Horton and Culver, in press). Maximum salinity values are found within the marsh fringe (23 psu) with an decrease to 8 psu, $112 \mathrm{~m}$ along the transect. The $\mathrm{pH}$ values show a gradual decline along 
the transect with high values within the tidal flat and marsh fringe, decreasing to a minimum of 5.1 at the landward edge of the transect. The percent clay fraction fluctuates along the transect with relatively high values within the marsh fringe and the landward edge of the transect (maximum of 29\%). Similar to salinity, LOI has relatively high values within the marsh fringe. Vegetation cover shows the expected increase inland along the transect, attaining 100\%, $32 \mathrm{~m}$ along the transect.

The Pea Island site is in a nature reserve located $14 \mathrm{~km}$ south of Oregon Inlet. Pamlico Sound adjacent to the study site had a salinity at the time of sample collection of c. 29 psu (somewhat higher than normal; Williams et al., 1973). The marsh is approximately $400 \mathrm{~m}$ wide and exhibits a narrow tidal flat, Spartina alterniflora, Juncus roemerianus and Spartina patens marsh environments. Porewater salinity increases from 23 psu, within the tidal flat stations of Pamlico Sound, to an exceptionally high value of $56 \mathrm{psu}, 193 \mathrm{~m}$ along the transect, at the transition between the Juncus roemerianus and Spartina patens marshes near a desiccated salt pond (Culver and Horton, 2005; Horton and Culver, in press). Salinity subsequently decreases to $12 \mathrm{psu}$ at the landward edge of the transect. The $\mathrm{pH}$ values exhibit a gradual gradient along the transect from 5.5 to 7.2. The clay fraction oscillates along the transect. LOI remains relatively low ( $<8 \%)$ within the tidal flat and Spartina alterniflora marsh, with a sharp increase to $27 \%$ at the transition between the Juncus roemerianus and Spartina patens marshes. Vegetation cover increases along the transect with two thresholds crossed at the transition between tidal flat and Spartina alterniflora marsh and between the Juncus roemerianus and Spartina patens marshes.

The core to which the transfer function was applied (SAL02S1P1) was taken at the southern margin of Clark’s Bay at Salvo, 14.5 km south of the Pea Island site. The back-barrier marsh at Salvo is about $400 \mathrm{~m}$ in width. A narrow, fringing Spartina alterniflora zone is succeeded landward by a broad Juncus roemerianus marsh. At the time of collection (August 2002), sea-grass wrack, driven onto the marsh by storms, had killed the Juncus grass and Salicornia bigelovii and Borrichia frutescens had 
colonized linear, coast-parallel zones of the marsh. The core was taken in one of these zones, $10 \mathrm{~m}$ from a creek where the salinity was 30 psu.

\section{Materials and methods}

\subsection{Modern samples}

We collected samples of surface sediment from a series of stations along transects from narrow tidal flat and vegetated marshes of the Currituck Barrier Island, Oregon Inlet and Pea Island sites to above Highest Astronomical Tide (HAT). We leveled all stations to benchmarks and elevations are expressed relative to mean sea level (MSL). At each station, we collected two samples of approximately $5 \mathrm{~cm}^{3}$ ( $5 \mathrm{~cm}^{2}$ surface sample by $1 \mathrm{~cm}$ thick) and $30 \mathrm{~cm}^{3}\left(30 \mathrm{~cm}^{2}\right.$ surface sample by 1 cm thick) volume for diatom and environmental analyses, respectively. Sampling intervals were determined according to changes in elevation and vegetation zones.

We mixed the $1 \mathrm{~cm}$ thick sediment samples for diatom analysis to average seasonal effects. In these intermittently high energy environments, the surface diatom assemblage at any sampling point is likely to be a mixture of locally produced taxa and transported taxa. Such a mixture of allochthonous and autochthonous diatom valves would also occur in sediments that accumulated in the past (Zong, 1997). Therefore, we do not attempt to separate the allochthonous component from the diatom assemblages. We prepared all diatom samples for investigation using light microscopy following standard methodology (Zong and Horton, 1998, 1999). Briefly, the samples were digested in 70$100 \mathrm{ml}$ of $20 \% \mathrm{H}_{2} \mathrm{O}_{2}$ by heating gently in a water bath for up to 24 hours, or until all organic matter was removed from the sample. Two and five drops of digested sample were pipetted on to two cover slips with 10 drops of distilled water and dried on a warm hotplate. Cover slips of differing concentration were then inverted and placed onto a glass slide, using Zrax, a high refractive index medium mountant. After further gentle heating and cooling we counted a minimum of 300 diatoms at 
a magnification of 1000 times using the keys of Hartley (1996), Van der Werff and Huls (1958-1966) and Patrick and Reimer (1975). The classification of salinity and life form is based on Denys (1991/2) and Vos and de Wolf (1993).

\subsection{Core collection}

We retrieved a $100 \mathrm{~mm}$ diameter push corer for laboratory and radiocarbon analyses. We instrumentally leveled the Salvo core to a benchmark and the elevation is expressed relative to MSL. In the laboratory, we cut centimeter slices of sediment from the core at specific sampling intervals for diatom and/or chronological analyses. The chronological framework for Salvo core SAL02S1P1 is provided by ${ }^{210} \mathrm{~Pb}$ and ${ }^{14} \mathrm{C}$ dating. We picked plant macrofossils from the peat for the radiocarbon assay. Total ${ }^{210} \mathrm{~Pb}$ was measured by alpha spectroscopy and followed the methodology of Nittrouer et al. (1979). Approximately $1.5 \mathrm{~g}$ of sediment was spiked with ${ }^{209} \mathrm{Po}$, as a yield determinant, and partially digested with $8 \mathrm{~N} \mathrm{HNO}_{3}$ by microwave heating. ${ }^{210,}{ }^{209} \mathrm{Po}$ from the solution was then electrodeposited onto nickel planchets in a dilute acid solution (modified from Flynn, 1968). Excess

${ }^{210} \mathrm{~Pb}$ activities were determined by subtracting the total ${ }^{210} \mathrm{~Pb}$ from that supported by ${ }^{226} \mathrm{Ra}$. Supported ${ }^{210} \mathrm{~Pb}$ activities were assumed to be equal to the deepest sediment samples in the core and verified by direct gamma counting.

Samples analyzed by direct gamma counting were initially dried homogenized and packed into standardized vessels before counting for at least 24 hours. Detectors were calibrated using a natural matrix standard (IAEA-300) at each energy of interest in the standard counting geometry for the associated detector. Supported ${ }^{210} \mathrm{~Pb}$ activities $\left({ }^{226} \mathrm{Ra}\right)$ were determined by allowing samples to equilibrate for greater than 3 weeks and recounting. ${ }^{226}$ Ra was then determined indirectly by counting the gamma emissions of its grand daughters, ${ }^{214} \mathrm{~Pb}(295$ and $351 \mathrm{keV})$ and ${ }^{214} \mathrm{Bi}(609 \mathrm{keV})$. 
The main processes governing excess ${ }^{210} \mathrm{~Pb}$ profiles are sediment accumulation, radioactive decay, and particle mixing (Goldberg and Koide, 1962). Dividing the ${ }^{210} \mathrm{~Pb}$ profile into a two-layer profile, a surface mixed layer extending to some depth in the sediment profile above a zone of no mixing, allows the sedimentation rate to be calculated in the region of limited mixing via:

$A_{x}=A_{o} e^{-\lambda / S}$

where $A_{x}$ and $A_{o}\left(d p m L^{-1}\right)$ represents the excess ${ }^{210} \mathrm{~Pb}$ activity at depth $\mathrm{x}(\mathrm{cm})$ and the surface sediment (or at the division of the mixing layer), respectively; $\mathrm{S}$ is the sedimentation rate ( $\left.\mathrm{cm} \mathrm{y}^{-1}\right)$; and $\lambda$ is the decay constant of ${ }^{210} \mathrm{~Pb}\left(0.031 \mathrm{y}^{-1}\right)$ (Appleby and Oldfield, 1992). Parameterizing the ${ }^{210} \mathrm{~Pb}$ profile and calculating the sedimentation rate below the mixing zone assumes that particle reworking rates are not significant over the depth interval of calculation, and that fluxes of both sediments and ${ }^{210} \mathrm{~Pb}$ have been constant over the age of the core.

We calibrated the radiocarbon date using the Intcal98 calibration curve (Stuiver et al., 1998) and combined with the ${ }^{210} \mathrm{~Pb}$ ages and associated stratigraphic information using OxCal (ver 3.5: Bronk Ramsey, 1995, 1998). We interpolated the resulting sequence of ages (Table 1) to produce the general accumulation history used to constrain temporally the variations in MSL identified from the diatom data.

\section{Diatom distributions}

We employed two multivariate methods to detect, describe and classify the elevational distribution of diatoms at each site: unconstrained cluster analysis; and detrended correspondence analysis (DCA). Unconstrained cluster analysis based on unweighted Euclidean distance, using no transformation or standardization of the percentage data, is used to classify modern samples into more-or-less homogeneous faunal zones (clusters). DCA is an ordination technique and is used to represent 
samples as points in a multi-dimensional space. Similar samples are located together and dissimilar samples apart. Birks (1986, 1992) stressed the complementarity of the cluster analysis and ordination techniques. Cluster analysis is effective in classifying the samples according to their diatom assemblage but DCA gives further information about the pattern of variation within and between groups. This is important as the precise boundaries between clusters can be arbitrary. Using this combination of techniques we delimit diatom zones on the basis of sample clusters that are mutually exclusive in ordination space. The elevation of each station within the reliable clusters determines the vertical zonation of each saltmarsh environment.

\subsection{Currituck Barrier Island Marsh}

The Currituck marsh has the lowest species diversity of the three study sites; we identified 56 species of diatoms (> 2\% relative abundance) from the 14 surface samples. The diatom assemblages are dominated by oligohalobous-indifferent species (e.g. Navicula tripunctata, Nitzschia palea and Cocconeis placentula), with significant influences from oligohalobous-halophilus (e.g. Cyclotella meneghiniana and Navicula arvensis) and mesohalobous species (e.g. Nitzschia obtuse). Cocconeis placentula, Cyclotella meneghiniana and Navicula arvensis dominate the tidal flat and marsh fringe section of the transect ( $0 \mathrm{~m}$ to $14 \mathrm{~m}$ along the transect) with maximum percentages $(19 \%, 11 \%$ and $10 \%$, respectively) within the Sound (Figure 2). The transition within the marsh fringe and Spartina cynusoroides marsh community corresponds to a rapid increase in the relative abundance of Navicula tripunctata and Nitzschia palea, which reach their maximum abundance (25\% and 14\%, respectively) $106 \mathrm{~m}$ along the transect.

Cluster analysis of diatom assemblages at each station detects two cluster zones (Figure 3). Zone C-I is dominated by species associated with vegetation including the brackish/freshwater epiphyte (live attached to a living plant) Cocconeis placentula with other frequencies of the freshwater epiphyte Nitzschia palea, the brackish/freshwater planktonic species Cyclotella meneghiniana and Navicula 
arvensis. The elevational range is from $-0.17 \mathrm{~m}$ to $0.51 \mathrm{~m}$ above MSL (a vertical range of $0.68 \mathrm{~m})$. Zone C-II is dominated by oligohalobous species, notably the oligohalobous-indifferent species Navicula tripunctata which can resist periods of desiccation and the freshwater epiphyte Nitzschia palea. The zone spans an elevation range of $0.07 \mathrm{~m}$ ( $0.51 \mathrm{~m}$ to $0.58 \mathrm{~m}$ above MSL).

\subsection{Oregon Inlet Marsh}

We identified 64 diatom species (> 2\% relative abundance) from the 15 surface samples. The assemblage is dominated by the polyhalobous species, such as Paralia sulcata, Opephora marina and Dimeregramma minor, representing $39 \%$ of the total assemblage (Figure 4). Oligohalobousindifferent (e.g. Navicula pelliculosa and Navicula lateropunctata) and mesohalobous (e.g. Navicula pygmaea) are also significant contributors to the total assemblage. Opephora marina, Dimeregramma minor and Navicula pelliculosa occupy the tidal flat (0-2 $\mathrm{m}$ along the transect) reaching relative abundances of $10 \%, 13 \%$ and $9 \%$, respectively. These species and other polyhalobous taxa are replaced by oligohalobous species, such as Navicula lateropunctata within the marsh fringe (4 m to $22 \mathrm{~m}$ along the transect). The assemblages within the Juncus roemerianus marsh are a combination of polyhalobous, oligohalobous-indifferent and mesohalobous species, with a notably increase in certain polyhalobous species (Paralia sulcata and Cocconeis scutellum) at the landward edge of the transect.

Three zones are identified by cluster analysis (Figure 5). Zone OI-I extends from $-0.83 \mathrm{~m}$ to $0.10 \mathrm{~m}$ above MSL with an elevational range of $0.93 \mathrm{~m}$, and is dominated by the marine/brackish episammic (live attached to sand grains) species Opephora marina and Dimeregramma minor. Zone OI-II is dominated by the marine planktonic species Paralia sulcata and Navicula lateropunctata, and ranges from $0.23 \mathrm{~m}$ to $0.38 \mathrm{~m}$ above MSL. Zone OI-III extends from $0.40 \mathrm{~m}$ to $0.42 \mathrm{~m}$ above MSL and is composed of Paralia sulcata and the marine/brackish episammic species Cocconeis scutellum. 


\subsection{Pea Island Marsh}

Pea Island Marsh has the highest species diversity of the three study sites; we identified 70 diatom species (> 2\% relative abundance) from the 17 surface samples $(0-1 \mathrm{~cm})$. All salinity classifications are found in high abundances. However, polyhalobous (Opephora marina and Diploneis smithii) and oligohalobous-halophilus (Amphora veneta, Nitzschia inconspicua and Navicula cincta) taxa dominate the assemblages (Figure 6). The tidal flat sampling stations have a mixed assemblage, dominated by polyhalobous Opephora marina, mesohalobous, Mastogloia lanceolata and oligohalobous-halophilus Fragilaria pinnata. The later two species are replaced within the Spartina alterniflora floral environments by Amphora veneta, Nitzschia inconspicua, Navicula cincta and Diploneis smithii.

Cluster analysis detects two cluster zones (Figure 7): Zone PI-I is dominated by the marine episammic species Opephora marina and species including Mastogloia lanceolata and the brackish/freshwater tychoplanktonic (live in plankton, but are derived primarily from other habitats) species Fragilaria pinnata with an elevational range of $-0.05 \mathrm{~m}$ to $0.36 \mathrm{~m}$ above MSL; and Zone O-II is dominated by Amphora veneta a benthic species tolerant of periodic wet subaerial environments (Hudstedt, 1953, 1957), Nitzschia inconspicua, and the marine/brackish epipelon taxa Navicula cincta and Diploneis smithii with an elevational range of $0.33 \mathrm{~m}$ to $0.52 \mathrm{~m}$ above MSL.

\section{Discussion}

A prerequisite of employing microfossils to determine former sea levels is that their controlling environmental variables are established (Thomas and Varekamp, 1991). The diatom assemblages of Currituck Barrier Island, Oregon Inlet and Pea Island marshes show vertical zonations suggesting that distribution of diatoms in saltmarsh environments are a function of elevation (e.g. Zong and Horton, 1998). Thus, we combined the data from the three study sites to produce a regional training set and have employed partial canonical correspondence analysis (CCA) to further study the relationship 
between diatoms and elevation (Table 2). Partial CCAs of the diatom and environmental data from the three study sites support the hypothesis that diatom assemblages are related to elevation and hence submergence. The six environmental variables (elevation, salinity, $\mathrm{pH}$, LOI, clay fraction and vegetation cover) account for 31\% of the explained variance in the diatom data. However, $69 \%$ total variation of the diatom data remains unexplained. Whether this is due to some overlooked factor (e.g. between-site variation in diatom composition) or to a large amount of stochastic variation remains unclear. Nevertheless, the explained percentage is considerably greater than those found in many other similar biological datasets, which have a large number of samples with many zero values, and have been used to develop transfer functions (Jones and Juggins 1995; Gasse et al., 1997; Zong and Horton, 1999; Sawai et al., 2004a). Partial CCAs show that the total explained variance is composed of $18 \%$ (elevation), $17 \%$ (clay fraction), $14 \%$ (LOI), $12 \%$ (vegetation cover), $11 \%$ (salinity) and 9\% (pH). The associated Monte Carlo permutation tests ( $\mathrm{p}=0.02$, 499 permutations under reduced model) indicate that all these variables, except $\mathrm{pH}$, are highly significant. Therefore, each of these gradients accounts for a significant proportion of the total variance in the diatom data. The relatively high inter-correlation (19\%) between variables indicates the elevational gradient cannot be considered completely independent. In reality, the structure of diatom assemblages is more likely to be jointly affected by many linear or non-linear related factors (Bé, 1977). This is to be expected because the other variables are dependent on the frequency of flooding. Similar inter-correlations among variables have been observed during the production of other modern diatom (Jones and Juggins, 1995; Gasse et al., 1997; Zong and Horton, 1999; Sawai et al., 2004 a, b) and foraminiferal (Horton et al., 1999, 2003; Horton and Edwards, 2005, in press; Horton and Culver, in press) datasets.

\subsection{Transfer function development}

Given that the distribution of saltmarsh diatoms is strongly influenced by surface elevation, we can use diatoms as 'proxies' for elevation, providing a suitable means of converting faunal data into environmental (e.g. elevation) data can be found. A transfer function quantifies this relationship 
between the environmental variable of interest and the environmental proxy so that the former may be expressed as a function of the latter. Birks (1995) outlined the general application of transfer functions to paleoenvironmental reconstruction, and here we concentrate on their use as it relates to diatoms and sea-level reconstruction (e.g. Hemphill-Haley, 1995 b, c; Zong and Horton, 1999; Sherrod, 1999; Gehrels et al., 2001, Zong et al., 2001; Sawai et al., 2004a, b). For the purpose of this paper, it is sufficient to note that the transfer function is a means of quantifying the ecological optima and tolerance of each species based on their modern response to environmental conditions.

We developed a diatom-based transfer function using a unimodal-based technique known as weighted averaging partial least squares (WA-PLS). The performance of each transfer function was assessed in terms of the root-mean square of the error of prediction (RMSEP) and the squared correlation $\left(r^{2}\right)$ of observed versus predicted values. The RMSEP indicates the systematic differences in prediction errors, whereas the $r^{2}$ measures the strength of the relationship of observed versus predicted values. These statistics were calculated as 'apparent' measures in which the whole training set was used to generate the transfer function and assess the predictive ability. The data were also jack-knifed (also known as 'leave-one-out' measures). Jack-knifing is a measure of the overall predictive abilities of the dataset.

A regional transfer function was developed for elevation based on 117 species and 46 samples from Currituck Barrier Island, Oregon Inlet and Pea Island marshes. The transfer function produces results for six components. The choice of component depends upon the prediction statistics (RMSEP and $r^{2}$ ) and the principle of parsimony, i.e. choosing the lowest component that gives an acceptable model. Therefore, we have chosen component two because it performs significantly better than component one when jack-knifed errors are considered: prediction errors are lower and squared correlations are higher (Table 3). Using component two, the relationship between observed and diatom-predicted elevation is very strong (Figure 8), which illustrates the powerful performance of the WA-PLS transfer functions $\left(r^{2}\right.$ jack $\left.=0.81\right)$. Indeed, these results indicate that very precise reconstructions of 
former sea levels are possible. The transfer function provides an error estimate for samplespecific former sea-level reconstructions $\left(\right.$ RMSEP $\left._{\text {jack }}=0.08 \mathrm{~m}\right)$, which is less than or equal to other regional transfer functions from temperate marshes and tropical mangroves (e.g. Horton et al., 1999, 2003; Zong and Horton, 1999; Gehrels, 2000; Gehrels et al., 2001; Horton and Edwards 2005, in press; Edwards et al., 2004a, b; Sawai et al., 2004a, b).

Caution should, however, be exercised when applying such transfer functions since several characteristics within the contemporary and fossil data may affect the accuracy of sea level reconstructions. The accuracy of the transfer function is hindered by spatial and temporal diatom variations. WA-PLS transfer functions also calibrate the diatom data to one environmental variable (elevation). This may unrealistically force the influence of all environmental factors onto a single parameter and give misleading results (Le, 1992; Huntley, 1993). A potentially more serious problem is post-depositional changes of diatom assemblages (e.g. frustule transport and taphonomy). Thus, samples may violate one of the basic assumptions of quantitative paleoenvironmental reconstructions (Birks 1995): the taxa in the training or calibration set and their ecological responses to the environmental variable(s) of interest have not changed significantly over the time span represented by the fossil assemblage.

\subsection{Transfer function application}

The transfer function is used to calibrate the fossil diatom assemblages collected from Salvo core SAL02S1P1. The calibration process assigns a paleomarsh-surface elevation to each fossil sample together with sample-specific standard errors of prediction for individual fossil samples (bootstrapped standard error of prediction).

The Salvo core comprises $4 \mathrm{~cm}$ of grey sand, which is overlain by $51 \mathrm{~cm}$ of brown peat (Figure 9a). The modern surface of the core rests at $0.14 \mathrm{~m}$ above MSL. We identified a total of 53 diatom species 
from 18 samples. The core is dominated by polyhalobous and mesohalobous taxa such as the tychoplanktonic benthic species Actinocyclus octonarius, Diploneis bombus (marine brackish epipelon, that is, it lives on or in substrate), Diploneis smithii, Opephora marina, Paralia sulcata, and the marine/brackish epipelon taxa (Navicula digitoradiata and Nitzschia scalaris. The reconstructed paleomarsh-surface elevations derived from the transfer function reflect the changes in diatom assemblages and are summarized in Figure 9a. The highest $(0.51 \pm 0.21 \mathrm{~m})$ and lowest $(0.22 \pm 0.05$ m) reconstructed elevations occur within the peat, and are associated with relatively high and low abundances of the polyhalobous species Diploneis smithii, respectively. The high elevation reconstruction is also derived from a sample with unusually high relative abundances of Nitzschia scalaris (> 20\%) when compared with the maximum abundance recorded in the modern dataset (8\%). As a result this sample has a large associated error term and its reconstructed elevation should therefore be treated with caution.

To illustrate fully the potential application of the transfer function technique, we place the diatombased reconstructions from the Salvo core into a temporal framework established from the associated chronological data presented in Table 1 . Sample ages were derived by linear interpolation between dated horizons. Alternative interpolation methods (e.g. a single best-fit polynomial curve) do not significantly alter the inferred age-depth relationship or the resulting pattern of relative sea-level change. The resulting curve is presented in Figure $9 \mathrm{~b}$ and suggests an overall rise of around $0.7 \mathrm{~m}$ during the last c. 150 years, at a long-term average rate of $3.7 \mathrm{~mm} \mathrm{yr}^{-1}$. This value is slightly higher than other studies examining relative sea-level changes over the last few centuries in neighboring areas, and may reflect the influence of local processes such as sediment consolidation or greater crustal subsidence due to postglacial fore-bulge collapse. For example, to the north of the study area, in Chesapeake Bay, Froomer (1980) identified a $2.74 \mathrm{~mm} \mathrm{yr}^{-1}$ rise during the last three centuries and Stevenson et al. (2002) suggested a rate of more than $3.2 \mathrm{~mm}$ per year during the 20th century. Further along the coast in Connecticut, Varekamp et al. (1992), Nydick et al. (1995) and Thompson et al. (1999) estimated that relative sea-levels have risen between 0.3 and $0.6 \mathrm{~m}$ since c. 1800, whilst van 
de Plassche et al. (1998) preferred a value of little over $1 \mathrm{~mm} \mathrm{yr}^{-1}$. In New England, Donnelly et al. (2004) documented a linear rate of sea-level rise of $1.0 \mathrm{~mm} \mathrm{yr}^{-1}$ from the 14th to the mid-19th century, with an acceleration to $2.8 \mathrm{~mm} \mathrm{yr}^{-1}$ from 1856-2001.

Over shorter periods of time, instrumental data from tide gauges are available for comparison with the transfer function data. Tide gauge data for the area cover the last 70 to 80 years and record relative sea-level rises of $2.22 \pm 0.25 \mathrm{~mm} \mathrm{yr}^{-1}$ at Wilmington, North Carolina (1935-1999) and $4.42 \pm 0.16$ mm $\mathrm{yr}^{-1}$ at Sewells Point, Virginia (1927-1999). Over a similar time interval, the Salvo core data suggests an average rate of relative sea-level rise of c. $4.5 \mathrm{~mm} \mathrm{yr}^{-1}$, which is toward the upper end of the instrumental record.

Whilst the reconstructions from the Salvo core are of relatively low temporal resolution (1 sample every c. 20 years), these data suggest small amplitude oscillations of around $10-20 \mathrm{~cm}$ are superimposed on the long-term rise in relative sea-level. Additional cores with smaller sampling intervals will be necessary to determine the significance of these oscillations. Nevertheless, these data demonstrate that the transfer function approach can provide an accurate and precise assessment of relative sea-level change within a study area. The collection of this type of sequential data has the potential to produce high-resolution records of sea-level change that are necessary to further research into sub-millennial sea level variability (Horton and Edwards, 2005).

\section{Concluding remarks}

We collected modern diatom samples from Currituck Barrier Island, Oregon Inlet and Pea Island marshes, Outer Banks, North Carolina, USA to elucidate the relationship of the diatom assemblages with elevation and environment. Multivariate analyses separate the saltmarsh diatom assemblages into distinct elevational zones, dominated by differing abundances of polyhalobous, mesohalobous and oligohalobous taxa: 
- Currituck Barrier Island marsh is the greatest distance from a major barrier island inlet and has low open water salinity. As a result, the assemblages consist of oligohalobous-indifferent species (e.g. Navicula tripunctata, Nitzschia palea and Cocconeis placentula), with significant influences from oligohalobous-halophilus (e.g. Cyclotella meneghiniana and Navicula arvensis) and mesohalobous species (e.g. Nitzschia obtuse);

- Oregon Inlet marsh is nearest the inlet and displays similar open water salinities to a normal marine environment. Thus the diatom assemblages are dominated by polyhalobous species indicative of this environment such as the marine planktonic species Paralia sulcata and the marine/brackish episammic taxa Opephora marina and Dimeregramma minor;

- Pea Island marsh has the highest species diversity of the three study sites, with taxa from the complete salinity spectrum, although it is dominated by polyhalobous (Opephora marina and Diploneis smithii) and oligohalobous-halophilus (Amphora veneta, Nitzschia inconspicua and Navicula cincta) taxa.

The strong relationship between elevation and the diatom assemblages at each site is supported by partial canonical correspondence analysis on the combined dataset from the three study sites, suggesting the distribution of saltmarsh diatoms is a direct function of elevation, with the most important controlling factors being the duration and frequency of subaerial exposure.

We developed the first diatom-based transfer function for the east coast of North America to reconstruct former sea levels with a precision of $\pm 0.08 \mathrm{~m}$. We applied the transfer function to construct a relative sea-level curve from fossil assemblages from Salvo, North Carolina. These results suggest a sea-level rise of $0.7 \mathrm{~m}$ sea-level rise over the last c. 150 years, at an average of $3.7 \mathrm{~mm} \mathrm{yr}^{-1}$, which is consistent with existing sea-level data, and illustrates the utility of the transfer function approach. The transfer function approach is part of a new generation of high-resolution sea-level reconstructions that is seeking to bridge the gap between short-term instrumental records that can be 
examined for signs of an accelerated rate of relative sea-level rise (e.g. Woodworth et al., 1999; Douglas et al., 2001) and long-term, traditional geological reconstructions or geophysical predictions that predict large-scale changes in land and ocean level (e.g. Peltier et al., 2002; Shennan and Horton, 2002). The approach is universally applicable, assuming the input data are adjusted for regional faunal differences.

\section{Acknowledgements}

We thank S. Riggs, D. Mallinson, D. Ames, J. Watson, C. Smith, S. Horton and A. Horton for their support and camaraderie. Permission to work on the Pea Island National Wildlife Refuge, the Cape Hatteras National Seashore and the Pine Island Hunt Club (Jeff Davenport) and funding for the USGS cooperative agreement award 02ERAG0044 is gratefully acknowledged. This research is part of the North Carolina Coastal Geology Cooperative Program (NCCGC). The paper is a contribution to IGCP Project 495 “Quaternary Land-Ocean Interactions: Driving Mechanisms and Coastal Responses.”

\section{References}

Appleby, P.G., Oldfield, F., 1992. Application of Pb-210 to sedimentation studies. In: Ivanovich, M., Harmon, R.S. (Eds.), Uranium-series Disequilibrium: Applications to Earth, Marine, and Environmental Problems, Claredon Press, Oxford, UK, 18-32.

Bé, A.W., 1977. An ecological, zoogeographic and taxonomic review of recent planktonic foraminifera. Oceanic Micropalaeontology 1, 1-100.

Birks, H.J.B., 1986. Numerical zonation, comparison and correlation of Quaternary pollenstratigraphical data. In: Berglund, B.E. (Ed.), Handbook of Holocene Palaeoecology and Palaeohydrology, John Wiley and Sons Ltd, London, 743-773. 
Birks, H.J.B., 1992. Some reflections on the application of numerical methods in Quaternary palaeoecology. University of Joensuu Publication, Karelian Institute 102, 7-20.

Birks, H.J.B., 1995. Quantitative palaeoenvironmental reconstructions. In: Maddy, D., Brew, J.S. (Eds.), Statistical modelling of Quaternary science data: Technical Guide No. 5, Quaternary Research Association, Cambridge, 161-236.

Bronk Ramsey, C., 1995. Radiocarbon Calibration and Analysis of Stratigraphy: The OxCal Program. Radiocarbon 37, 425-430.

Bronk Ramsey, C., 1998. Probability and Dating. Radiocarbon 40, 461-474.

Cooper, S.R., 1995. Chesapeake Bay watershed historical land use: impact on water quality and diatom communities. Ecological Applications 5, 703-723.

Cooper, S.R., 1999. Estuarine paleoenvironmental reconstructions using diatoms. In: Stoermer, E.F., Smol, J.P. (Eds.), The Diatoms: Application for the Environmental and Earth Sciences, Cambridge University Press, Cambridge, 352-373.

Cooper, S.R., Brush, G.S., 1991. Long-term history of Chesapeake Bay anoxia. Science 254, 992-996.

Cooper, S.R., Brush, G.S., 1993. A 2,500 year history of anoxia and eutrophication in Chesapeake Bay. Estuaries 16, 617-626.

Culver, S.J., Horton, B.P., 2005. Infaunal marsh foraminifera from the Outer Banks, North Carolina. Journal of Foraminiferal Research 35, 148-170.

Denys, L., 1991/1992. A check-list of the diatoms in the Holocene deposits of the western Belgian coastal plain with a survey of their apparent ecological requirements. Professional Paper, 246, Belgian Geological Survey, Belgium.

Donnelly, J.P., Cleary, P., Newby, P., Ettinger, R., 2004. Coupling instrumental and geological records of sea-level change: Evidence from southern New England of an increase in the rate of sea-level rise in the late 19th century. Geophysical Research Letters 31, 1-4.

Douglas, B.C., Kearney, M.S., Leatherman, S.P., 2001. Sea Level Rise: History and Consequences. San Diego, Academic Press, 65-95. 
Cleve, P.T., 1894-1895. Synopsis of the naviculoid diatoms. Kgl. Sven. Vet. Akad. Handl. 26/27, 1-194; 1-219.

Cleve-Euler, A., 1922. Om diatomacevegetationen och dess forandringar i Sabysjon, Uppland samt nagra damda sjoar i Salatrakten. Sveriges Geol. Undersokning 309, 1-76.

Edwards, R.J., Horton, B.P., 2000. High Resolution Records of Relative Sea-Level Change from U.K. Salt-marsh Foraminifera. Marine Geology 169, 41-56.

Edwards, R.J., Horton, B.P., in press. Developing High Resolution Records of Relative Sea-Level Change Using A Microfossil Transfer Function: An Example from North Norfolk, UK. Royal Society Special Publication.

Edwards R.J., van de Plassche O., Gehrels W.R., Wright A.J., 2004. Assessing Sea-Level Data From Connecticut, USA, Using A Foraminiferal Transfer Function For Tide Level. Marine Micropaleontology 51, 239-255.

Edwards R.J., Wright A.J., van de Plassche O., 2004. Surface distributions of salt-marsh foraminiferal from Connecticut, USA: Modern Analogues for high resolution sea-level studies. Marine Micropaleontology 51, 1-21

Froomer, N. L., 1980. Sea level changes in the Chesapeake Bay during historic times. Marine Geology 36, 289-305.

Flynn, W.W., 1968. The determination of low levels of polonium-210 in environmental materials. Anal. Chim. Acta 43, 221-227.

Gasse, F., Barker, P., Gell, P.A., Fritz, S.C., Chalie, F., 1997. Diatom-inferred salinity in palaeolakes: An indirect tracer of climate change. Quaternary Science Reviews 16, 547-563.

Gehrels, W.R., 2000. Using foraminiferal transfer functions to produce high-resolution sea-level records from salt-marsh deposits, Maine, USA. The Holocene 10, 367-376.

Gehrels, W.R., Roe, H.M., Charman, D.J., 2001 Foraminifera, testate amoebae and diatoms as sealevel indicators in UK saltmarshes: a quantitative multiproxy approach. Journal of Quaternary Science 16, 201-220. 
Gehrels, W.R., Belknap, D.F., Black, S. \& Newnham, R.M., 2002. Rapid sea-level rise in the Gulf of Maine, USA, since AD1800. The Holocene 12, 383-389.

Goldberg, E.D., Koide, M., 1962. Geochronologocal studies of deep-sea sediments by the ioniumthorium method. Geochim Cosmochim. Acta 26, 417-450.

Hartley, B., 1996. An Atlas of British Diatoms. Biopress Ltd. Bristol, England.

Hemphill-Haley, E., 1995a. Distribution and taxonomy of diatoms (Bacillariophyta) in surface samples and a two-meter core from Winslow Marsh, Bainbridge Island, Washington. U.S. Geological Survey Open File Report, 95-833, 105 pp.

Hemphill-Haley, E., 1995b. Diatom evidence for earthquake-induced subsidence and tsunami $300 \mathrm{yr}$ ago in southern coastal Washington. Geological Society of American Bulletin 107, 367-378.

Hemphill-Haley, E., 1995c. Intertidal diatoms from Willapa Bay, Washington: Application to studies of small scale sea-level changes. Northwest Science 69, 29-45.

Hendey, N.I., 1964. An introductory account of the smaller algae of British coastal waters, Bacillariophyceae (Diatoms). Fishery Investigation Series N, London, HMSO.

Horton, B.P., Culver, S.J., in press. Modern intertidal foraminifera of the Outer Banks, North Carolina, USA and their applicability for sea-level studies. Journal of Coastal Research.

Horton, B.P., Edwards, R.J., in press. Quantifying Holocene Sea Level Change Using Intertidal Foraminifera: Lessons from the British Isles. Journal of Foraminiferal Research Special Publication.

Horton, B.P., Edwards, R.J., 2005. The application of local and regional transfer functions to reconstruct former sea levels, North Norfolk, England. The Holocene 15, 216-228.

Horton, B.P., Edwards, R.J., Lloyd, J.M., 1999. Reconstruction of former sea levels using a foraminiferal-based transfer function. Journal of Foraminiferal Research 29, 117-129.

Horton, B.P., Edwards, R.J., Lloyd, J.M., 2000. Implications of a microfossil transfer function in Holocene sea-level studies. In: Shennan, I., Andrews, J.E. (Eds.), Holocene land-ocean interaction and environmental change around the western North Sea, Geological Society Special Publication 166, 41-54 
Horton, B.P., Larcombe, P., Woodroffe, S.E., Whittaker, J.E., Wright, M.W., Wynn, C., 2003. Contemporary foraminiferal distributions of the Great Barrier Reef coastline, Australia: implications for sea-level reconstructions. Marine Geology 3320, 1-19.

Hudstedt, F., 1953. Die Systematik der Diatomeen in ihren Beziehungen zur Geoligie und Okologie nebst einer Revisions des Halobien-systems, Sv. Bot. Tidskr. 47, 509-519.

Hudstedt, F., 1957. Die diatomeenflora des Fluss-systems der Weser im Gebiet der Hansestadt Bremen. Ab. Naturw. Bremen 34, 181-440.

Huntley, B., 1993. The use of climatic response surfaces to reconstruct palaeoclimate from Quaternary pollen and plant macrofossil data. Philosophical Transactions of the Royal Society of London 341, 215-224.

Imbrie, J., Kipp, N.G., 1971. A new micropalaeontological method for quantitative paleoclimatology: application to a late Pleistocene Caribbean core. In: Turekian (Ed.), The Late Cenozoic Glacial Ages. Yale University Press, New Haven and London, 71-181.

Jones, V. J., Juggins, S., 1995. The construction of diatom-based chlorophyll transfer function and its application at three lakes on Signy Island (maritime Antarctic) subject to differing degrees of nutrient enrichment. Freshwater Biology 34, 433-445.

Juggins, S., 1992. Diatoms in the Thames estuary, England: ecology, palaeoecology, and salinity transfer function. Bibliotheca Diatomologica 25, 216.

Kapruan, D.F., 1980. An Illustrated Guide to the Benthic Marine Algae of Coastal North Carolina. Lubrecht and Cramer, NY.

Laird, K., Edgar, R., 1992. Spatial distribution of diatoms in the surficial sediments of a New England salt marsh. Diatom Research 72, 267-279

Le, J., 1992. Paleotemperature estimation methods: sensitivity test on two western equatorial Pacific cores. Quaternary Science Reviews, 11, 801-820.

Nelson, A.R., Kashima, K., 1993. Diatom zonation in southern Oregon tidal marshes relative to vascular plants, foraminifera, and sea level. Journal of Coastal Research 9, 673-697. 
Nikitina, D.L., Pizzuto, J.E., Schwimmer, R.A., Ramsey, K.W. 2000. An updated Holocene sea-level curve for the Delaware Coast. Marine Geology 171, 7-20.

Nittrouer, C.A., Sternberg, R.W., Carpenter, R. \& Bennett, J.T., 1979. The use of ${ }^{210} \mathrm{~Pb}$ geochronology as a sedimentological tool: an application to the Washington continental shelf. Marine Geology 31, 297-316.

Nydick, K.R., Bidwell, A.B., Thomas, E., Varekamp, J.C. 1995. A sea-level rise curve from Guilford, Connecticut, USA. Marine Geology 124, 137- 159.

Patrick, R., Reimer, C.W., 1966 and 1975. The diatoms of the United States. The Academy of Natural Sciences of Philadelphia, Philadelphia.

Peltier, W.R., Shennan, I., Drummond, R., Horton, B. P., 2002. On the post-glacial isostatic adjustment of the British Isles and the shallow visco-elastic structure of the Earth. Geophysical Journal International 148, 443-475.

Round, F.E., 1991. The diatoms: biology and morphology of the genera. Cambridge University Press. Riggs, S.R., 2002. Life at the edge of North Carolina's coastal system: the geologic controls. In: Beal, C., Prioli, C., (Eds.) Life at the Edge of the Sea: Essays on North Carolina's Coast and Coastal Culture. Coastal Carolina Press, Wilmington, N.C., volume I, 63-95.

Sawai, Y., Nagumo, T., Horton, B.P., 2004a. Diatom-based elevation transfer function along the Pacific coast of eastern Hokkadio, northern Japan - an aid in paleo-seismic study along the coasts near Kurile subduction zone. Journal of Quaternary Science 23, 2467-2484.

Sawai, Y., Satake, K., Kamataki, T., Nasu, H., Shishikura, M., Atwater, B. F., Horton, B. P., Kelsey, H., Nagumo, T., Yamaguchi, M., 2004b. Transient uplift after a 17th-century earthquake along the Kuril trench. Science 206, 1918-1920.

Sherrod, B.L., 1999. Gradient analysis of diatom assemblages in a Puget Sound salt marsh: can such assemblages be used for quantitative paleoecological reconstructions? Palaeogeography, Palaeoclimatology, Palaeoecology 149, 213-226.

Shennan, I., Horton, B.P., 2002 Relative sea-level changes and crustal movements of the UK. Journal of Quaternary Science 16, 511-526. 
Stevenson, J.C., Kearney, M.S., Koch, E.W., 2002. Impacts of Sea Level Rise on Tidal Wetlands and Shallow Water Habitats: A Case Study from Chesapeake Bay. American fisheries Society Symposium 32, 23-36.

Stuiver M., Reimer, P.J., Bard, E., Beck, J.W., Burr, G.S., Hughen, K.A., Kromer, B., McCormac, G., van der Plicht, J., Spurk, M. 1998. INTCAL98 Radiocarbon Age Calibration, 24000-0 cal BP. Radiocarbon 40, 1041-1083.

Thomas, E., Varekamp, J.C., 1991. Palaeoenvironmental analysis of marsh sequences (Clifton, Connecticut): Evidence for punctuated rise in relative sea-level during the Holocene. Journal of Coastal Research Special Issue 11, 125-158.

Van de Plassche, O., van der Borg, K., de Jong, A., 1998. Sea level climate correlation during the past 1400 yr. Geology 26, 319- 322.

Varekamp, J.C., Thomas, E., van de Plassche, O., 1992. Relative sea-level rise and climate change over the last 1500 years. Terra Nova 4, 293-304.

Vos, P.C., de Wolf, H., 1993. Methodological aspects of palaeoecological diatom research in coastal areas of the Netherlands. Geologie en Mijnbouw 67, 31-40.

van der Werff, H., Huls, H., 1958-1966. Diatomeeenflora van Nederland. 8 parts. Published privately, De Hoef, The Netherlands.

Williams, A.B., Posner, G.S., Woods, W.J., Deubler, E.E. Jr., 1973, A Hydrographic Atlas of Larger North Carolina Sounds. UNC Sea Grant Publication, Chapel Hill, North Carolina, 129 p.

Wilson, S.E., Cumming, B.F., Smol, J.P., 1995. Assessing the reliability of salinity inference models from diatom assemblages: an examination of a 219-lake data set from western North America. Canadian Journal of Fisheries and Aquatic Science 53, 1580-1594.

Woodworth, P.L., Tsimplis, M.N., Flather, R.A., Shennan, I., 1999. A review of the trends observed in British Isles mean sea level data measured by tide gauges. Geophysical Journal International 136, 651-670.

Zong, Y., 1997. Mid and Late Holocene sea-level changes in Roudsea Marsh, northwest England: A diatom biostratigraphical Investigation. The Holocene 7, 311-323. 
Zong, Y., Horton, B.P., 1998. Diatom zones across intertidal flats and coastal saltmarshes in Britain. Diatom Research 13, 375-394.

Zong, Y., Horton, B.P., 1999. Diatom-based tidal transfer functions as an aid in reconstructing Quaternary history of sea-level movements in the UK. Journal of Quaternary Science 14, 153167.

Zong, Y., Shennan, I., Combellick, R.A., Hamilton, S., Rutherford, M.M., 2003. Microfossil evidence of pre-seismic land subsidence of the 1964 earthquake in Alaska. The Holocene 13, 7-20.

Zong, Y., Tooley, M.J., 1996. Holocene sea-level changes and crustal movements in Morecambe Bay, northwest England. Journal of Quaternary Science 11, 43-58. 


\begin{tabular}{|c|c|c|c|c|c|}
\hline \multirow[t]{2}{*}{ Method } & \multirow{2}{*}{$\begin{array}{l}\text { Elevation } \\
\text { (m MSL) }\end{array}$} & \multirow[t]{2}{*}{${ }^{14} \mathrm{C} /{ }^{210} \mathrm{~Pb}$ (yrs. BP) } & \multicolumn{3}{|c|}{ Calibrated Age Range (AD/BC) } \\
\hline & & & Max & Mid & Min \\
\hline${ }^{210} \mathrm{~Pb}$ & 0.14 & mixed/modern & & & \\
\hline${ }^{210} \mathrm{~Pb}$ & 0.12 & mixed/modern & & & \\
\hline${ }^{210} \mathrm{~Pb}$ & 0.10 & mixed/modern & & & \\
\hline${ }^{210} \mathrm{~Pb}$ & 0.08 & $11 \pm 1.2$ & 1989 & 1991 & 1993 \\
\hline${ }^{210} \mathrm{~Pb}$ & 0.06 & $15 \pm 1.6$ & 1984 & 1987 & 1991 \\
\hline${ }^{210} \mathrm{~Pb}$ & 0.04 & $18 \pm 2.0$ & 1981 & 1984 & 1987 \\
\hline${ }^{210} \mathrm{~Pb}$ & 0.02 & $22 \pm 2.4$ & 1977 & 1980 & 1984 \\
\hline${ }^{210} \mathrm{~Pb}$ & 0.00 & $25 \pm 2.8$ & 1973 & 1977 & 1981 \\
\hline${ }^{210} \mathrm{~Pb}$ & -0.02 & $29 \pm 3.2$ & 1969 & 1973 & 1978 \\
\hline${ }^{210} \mathrm{~Pb}$ & -0.04 & $33 \pm 3.6$ & 1963 & 1970 & 1976 \\
\hline${ }^{210} \mathrm{~Pb}$ & -0.06 & $36 \pm 4.0$ & 1960 & 1966 & 1972 \\
\hline${ }^{210} \mathrm{~Pb}$ & -0.08 & $40 \pm 4.4$ & 1955 & 1962 & 1969 \\
\hline${ }^{210} \mathrm{~Pb}$ & -0.10 & $44 \pm 4.8$ & 1950 & 1958 & 1965 \\
\hline${ }^{210} \mathrm{~Pb}$ & -0.12 & $47 \pm 5.2$ & 1945 & 1953 & 1961 \\
\hline${ }^{210} \mathrm{~Pb}$ & -0.15 & $56 \pm 6.2$ & 1936 & 1946 & 1956 \\
\hline${ }^{210} \mathrm{~Pb}$ & -0.18 & $75 \pm 13.1$ & 1913 & 1933 & 1953 \\
\hline${ }^{210} \mathrm{~Pb}$ & -0.21 & $94 \pm 21.1$ & 1890 & 1923 & 1955 \\
\hline${ }^{210} \mathrm{~Pb}$ & -0.24 & $113 \pm 31.1$ & 1875 & 1913 & 1950 \\
\hline${ }^{210} \mathrm{~Pb}$ & -0.27 & $131 \pm 42.0$ & 1860 & 1905 & 1950 \\
\hline${ }^{210} \mathrm{~Pb}$ & -0.30 & $150 \pm 54.2$ & 1840 & 1895 & 1950 \\
\hline $\begin{array}{c}\text { Radiocarbo } \\
n\end{array}$ & -0.34 & $200 \pm 35$ & 1790 & 1870 & 1950 \\
\hline
\end{tabular}

Table 1. Chronology for Salvo core SAL02S1P1. Radiocarbon date is calibrated using the Intcal98 calibration curve (Stuiver et al., 1998) and combined with the ${ }^{210} \mathrm{~Pb}$ ages and associated stratigraphic information using OxCal (ver 3.5: Bronk Ramsey, 1995, 1998). The resulting age chronology is reported in years Anno Domini / Before Christ (AD/BC). 


\begin{tabular}{llllll}
\hline Axis & $\mathbf{1}$ & $\mathbf{2}$ & $\mathbf{3}$ & $\mathbf{4}$ & Total inertia \\
\hline Eigenvalues & 0.39 & 0.33 & 0.23 & 0.14 & 4.07 \\
Species-environment correlations & 0.92 & 0.89 & 0.87 & 0.90 & \\
Cumulative percentage variance: & & & & & \\
-of species data & 9.6 & 17.8 & 23.3 & 26.8 & \\
-of species environment relationship & 31.4 & 58.3 & 76.5 & 87.7 & \\
& & & & & 4.07 \\
Sum of all eigenvalues & & & & & 1.24 \\
Sum of all canonical eigenvalues & & & & &
\end{tabular}

Table 2. Summary of CCA results from diatom assemblages of Currituck Barrier Island, Oregon Inlet and Pea Island marshes. 


\begin{tabular}{|c|c|c|}
\hline \multicolumn{3}{|c|}{ Estimated (apparent) errors } \\
\hline Component & RMSE & $r^{2}$ \\
\hline 1 & 0.09 & 0.79 \\
\hline 2 & 0.04 & 0.95 \\
\hline 3 & 0.03 & 0.97 \\
\hline 4 & 0.02 & 0.99 \\
\hline 5 & 0.02 & 0.99 \\
\hline \multicolumn{3}{|c|}{ Prediction (jack-knife) errors } \\
\hline Component & RMSEP & $r^{2}$ \\
\hline 1 & 0.12 & 0.60 \\
\hline 2 & 0.08 & 0.81 \\
\hline 3 & 0.08 & 0.82 \\
\hline 4 & 0.08 & 0.81 \\
\hline 5 & 0.09 & 0.79 \\
\hline
\end{tabular}

Table 3. Statistics summary of the performance of weighted averaging partial least squares (WA-PLS) from diatom assemblages of Currituck Barrier Island, Oregon Inlet and Pea Island marshes. 


\section{Figures}
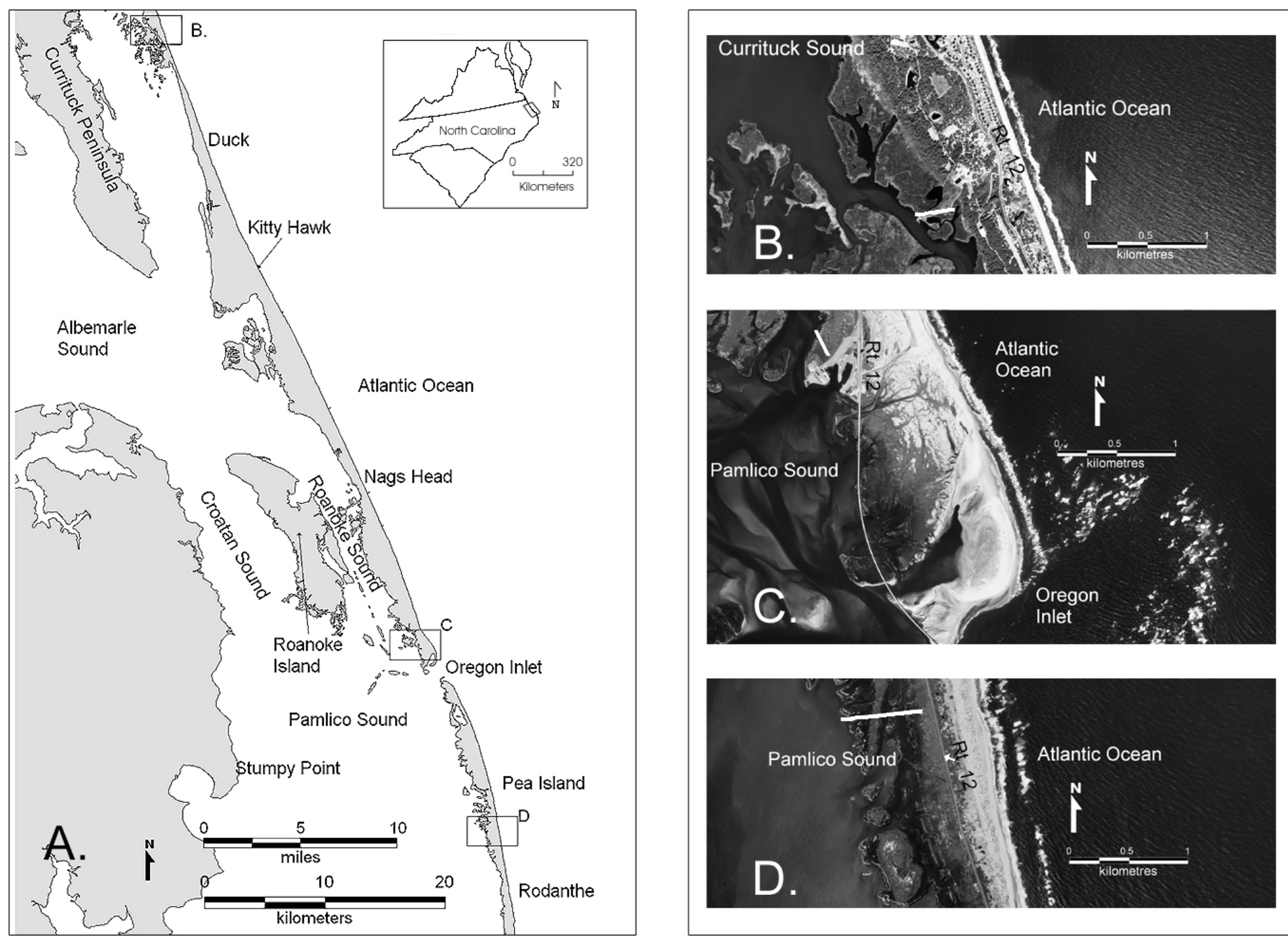

Figure 1. (A) Location map of Outer Banks with inserts of the three study sites, (B) Currituck Barrier Island, (C) Oregon Inlet and (D) Pea Island marshes. White lines on B, C and D indicate transect sites. 


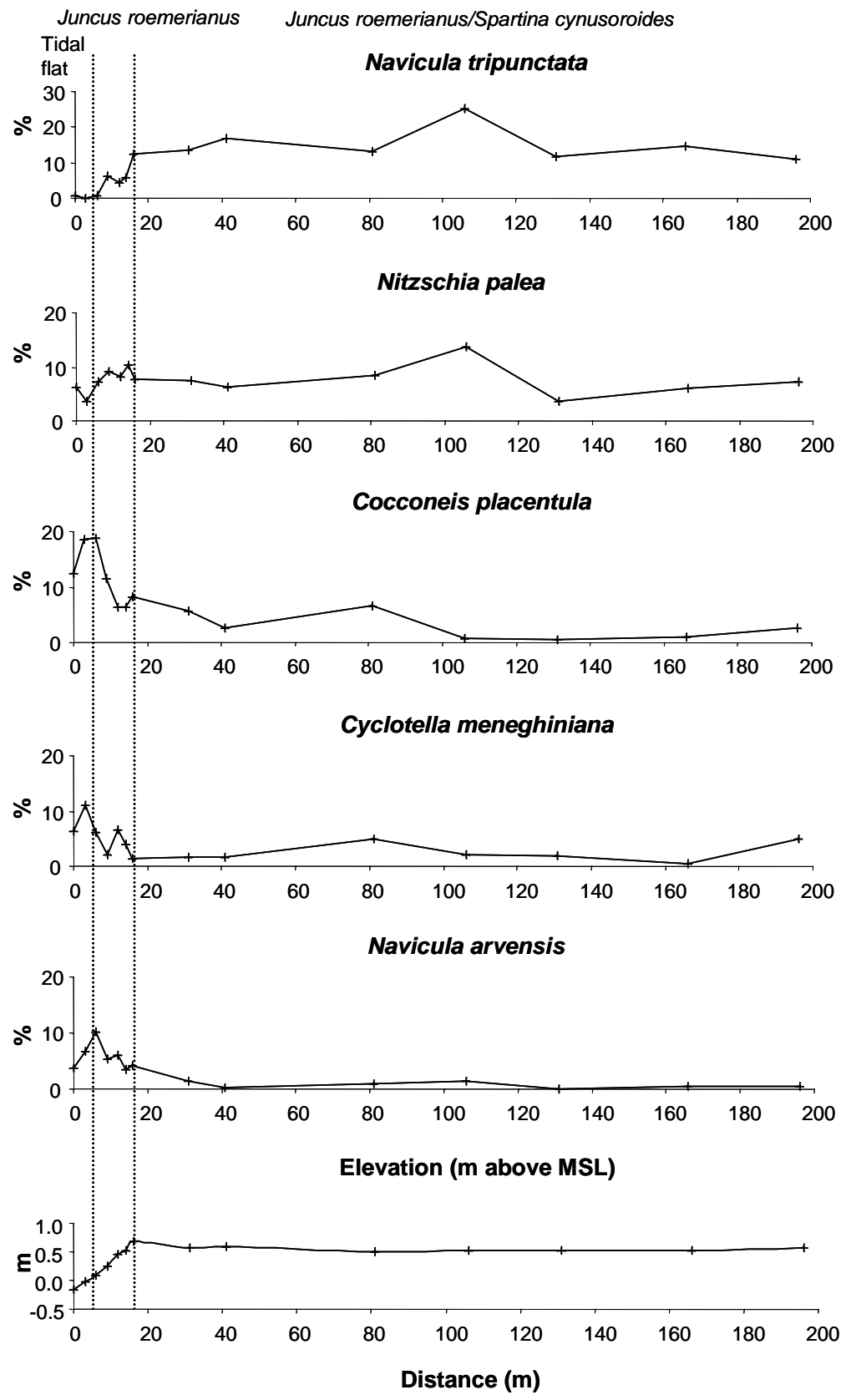

Figure 2. Relative abundance of dead specimens of selected diatom species of Currituck Barrier Island marsh. The elevation and vascular plant zonation are indicated. 


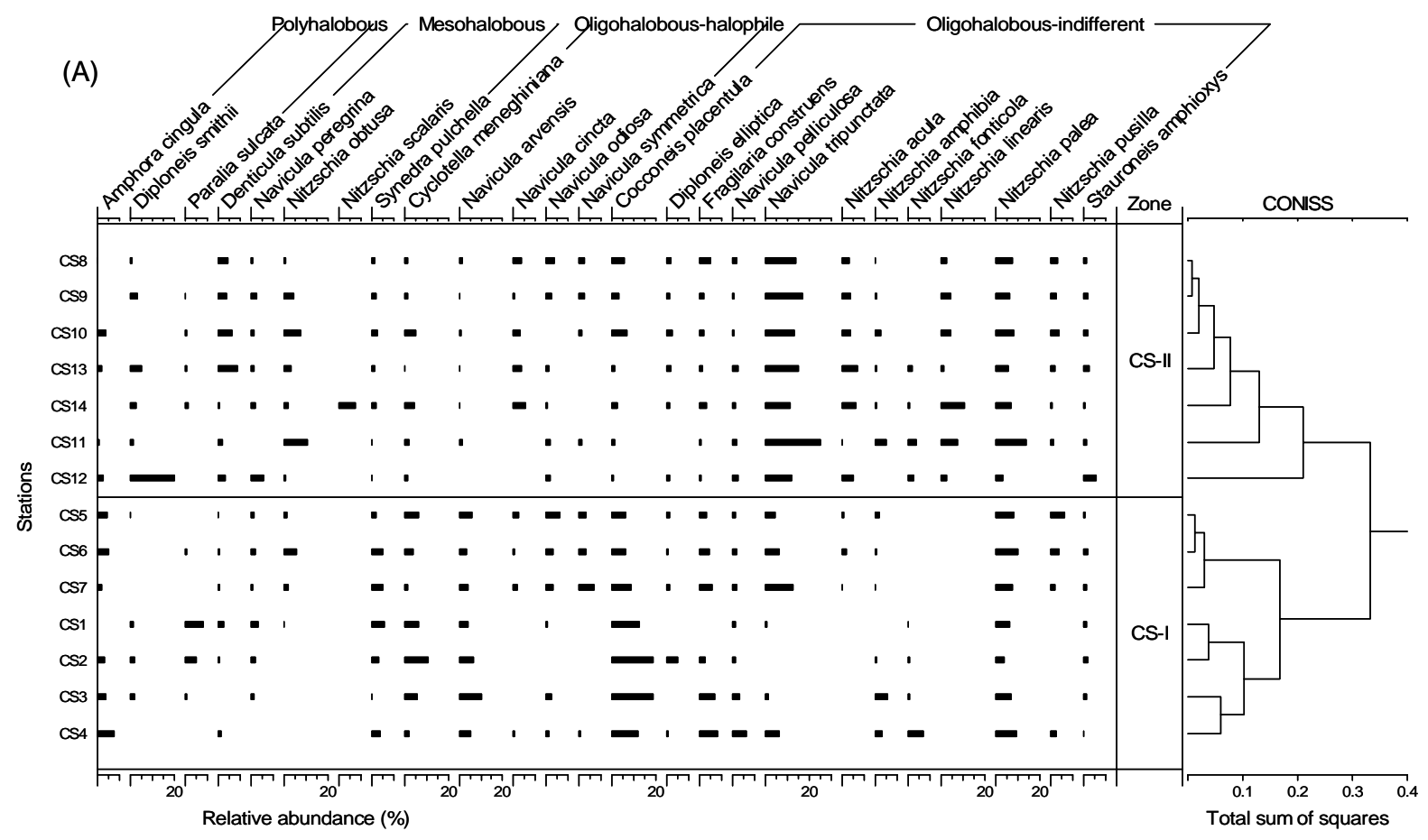

(B)
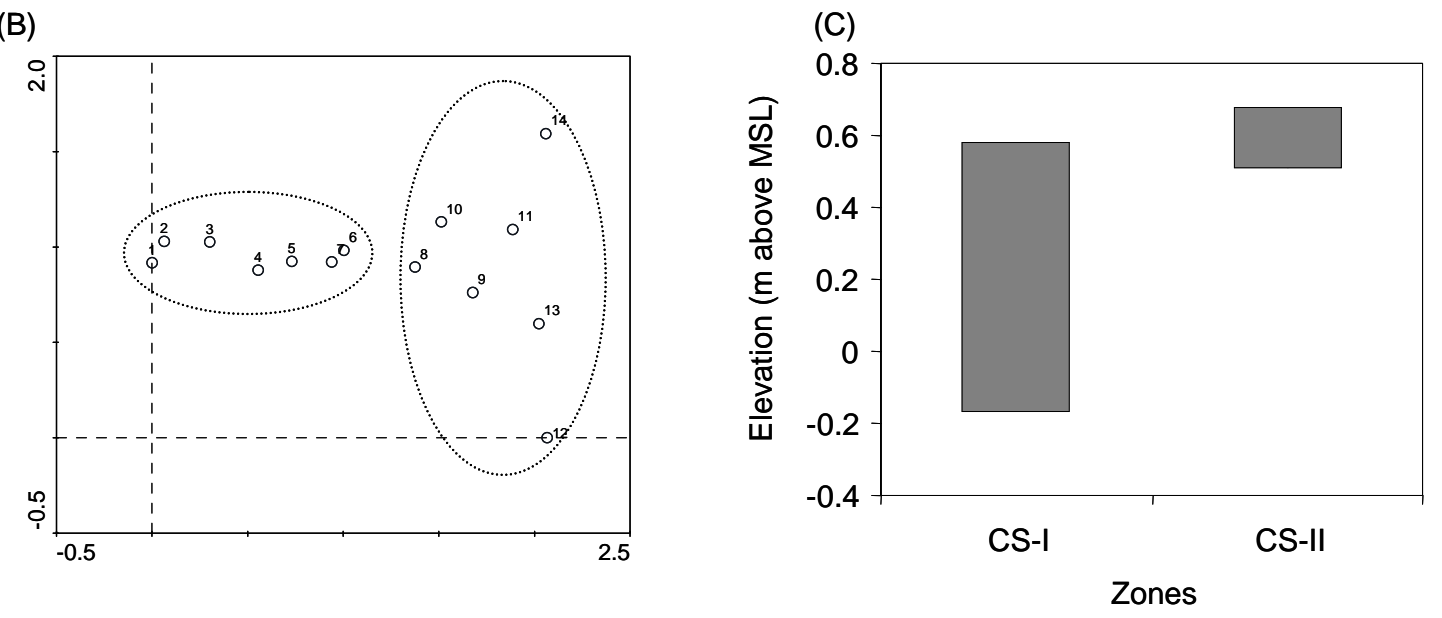

Figure 3. (A) Unconstrained cluster analysis based on unweighted Euclidean distance (species $>5 \%$ are shown) (B) detrended correspondence analysis and (C) vertical zonation of diatom assemblages (\%) from Currituck Barrier Island marsh. 


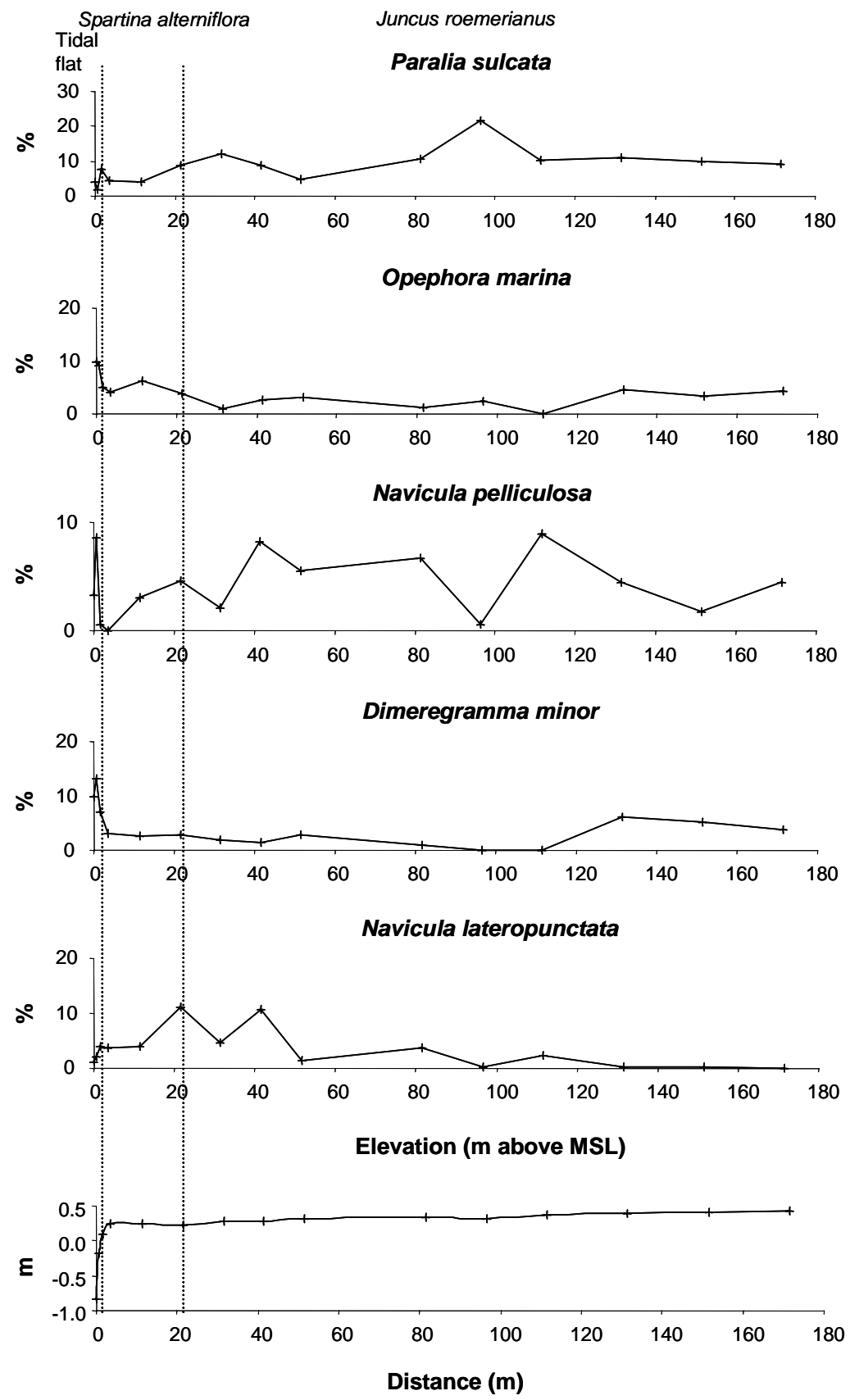

Figure 4. Relative abundance of dead specimens of selected diatom species of Oregon Inlet marsh. The elevation and vascular plant zonation are indicated. 


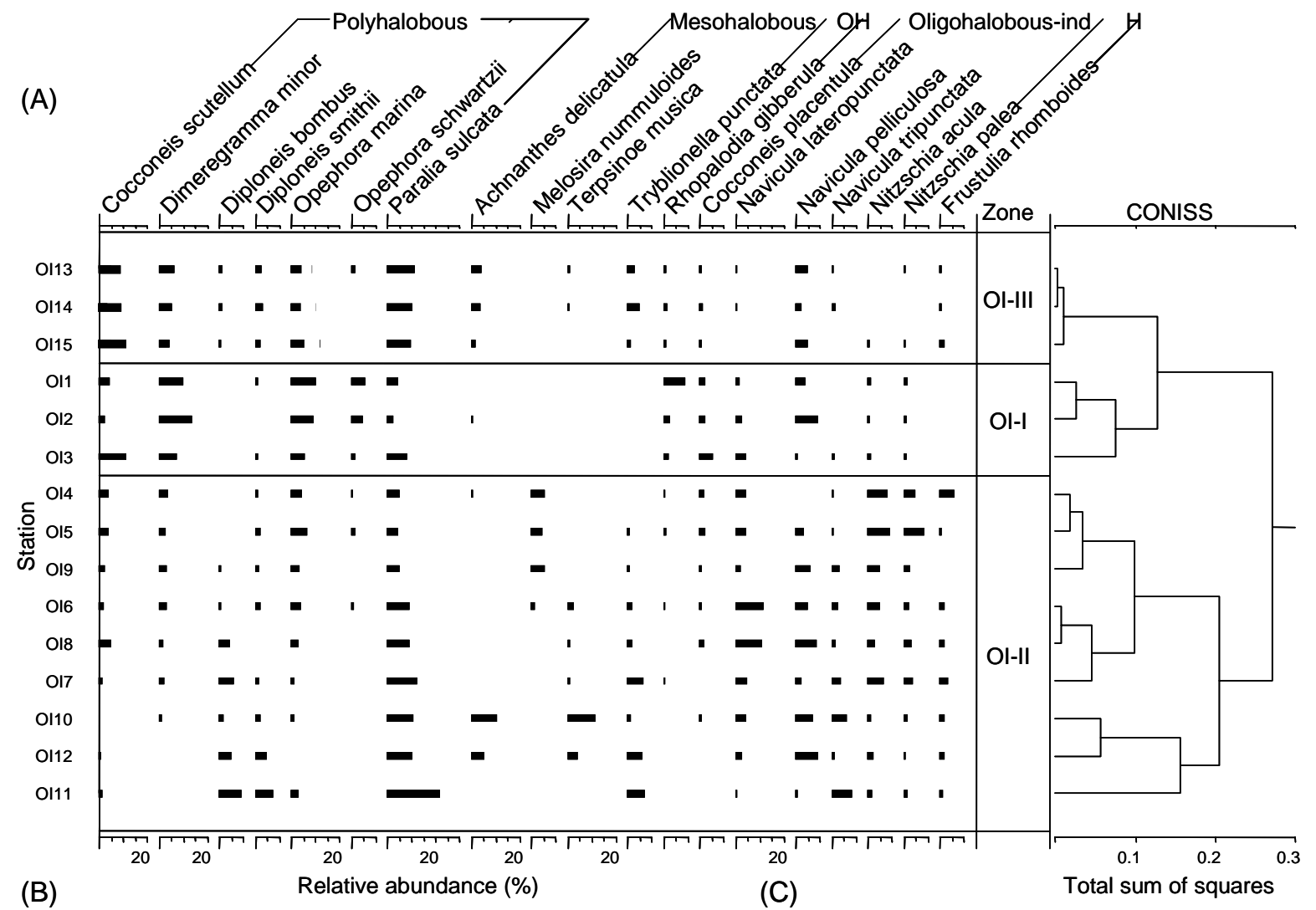

(B)
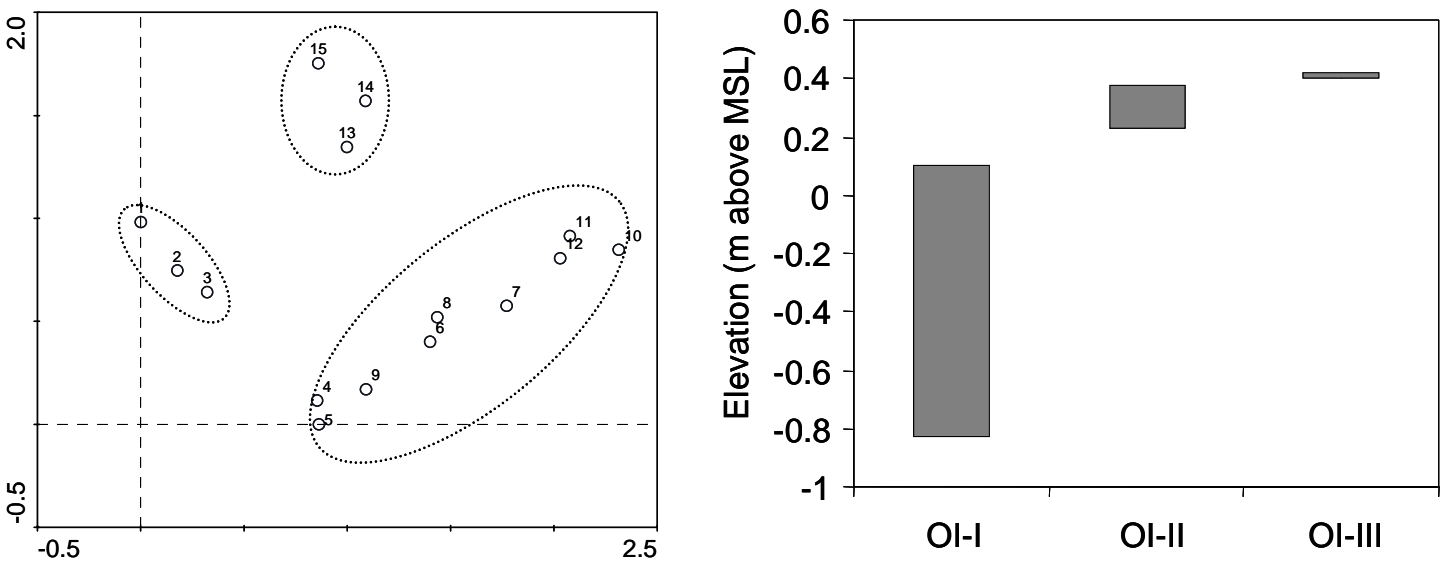

Zones

Figure 5. (A) Unconstrained cluster analysis based on unweighted Euclidean distance (species $>5 \%$ are shown) (B) detrended correspondence analysis and (C) vertical zonation of diatom assemblages (\%) from Oregon Inlet marsh. $\mathrm{OH}$ = oligohalobous-halophilus; $\mathrm{H}$ = halophobous 


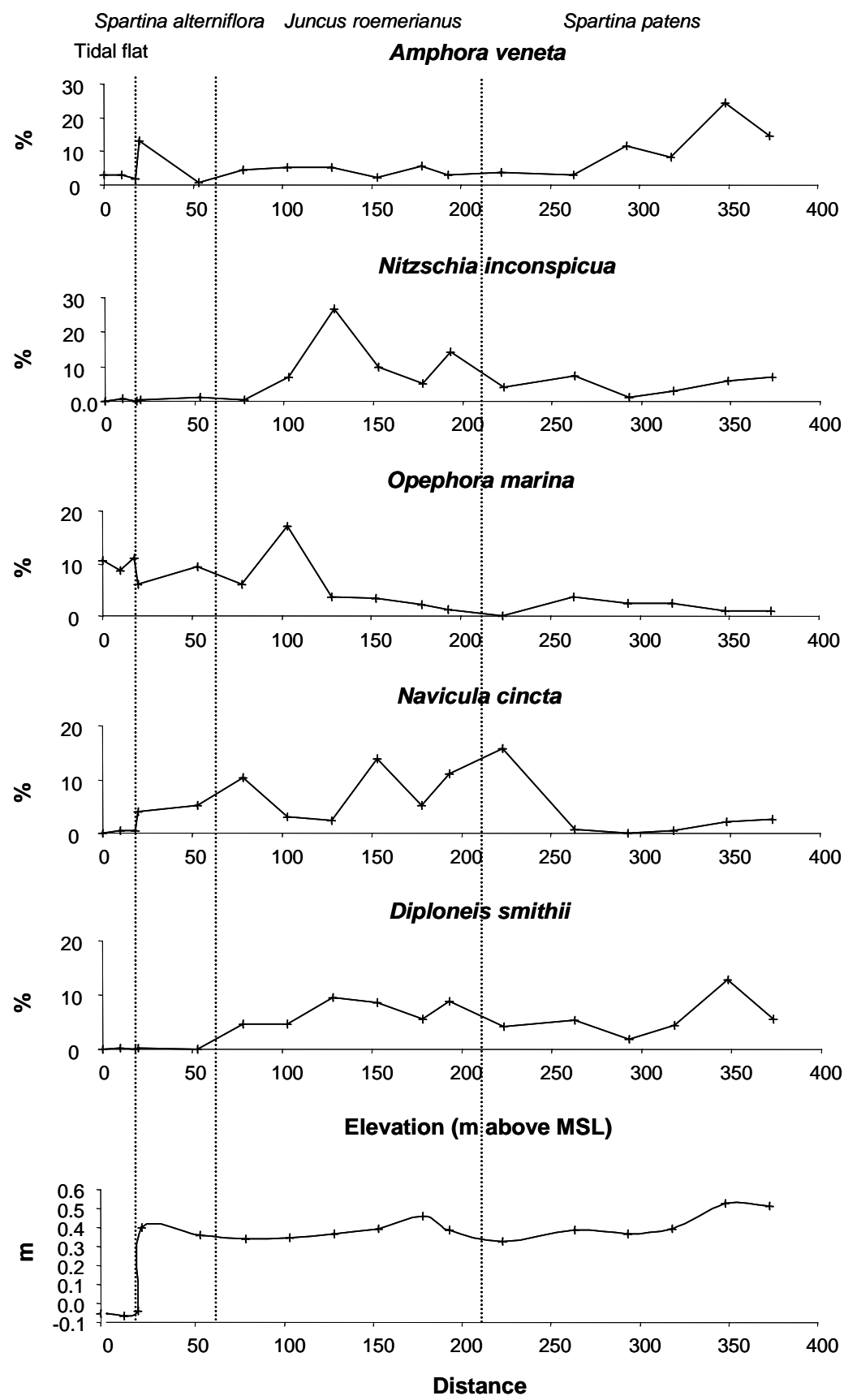

Figure 6. Relative abundance of dead specimens of selected diatom species of Pea Island marsh. The elevation and vascular plant zonation are indicated. 


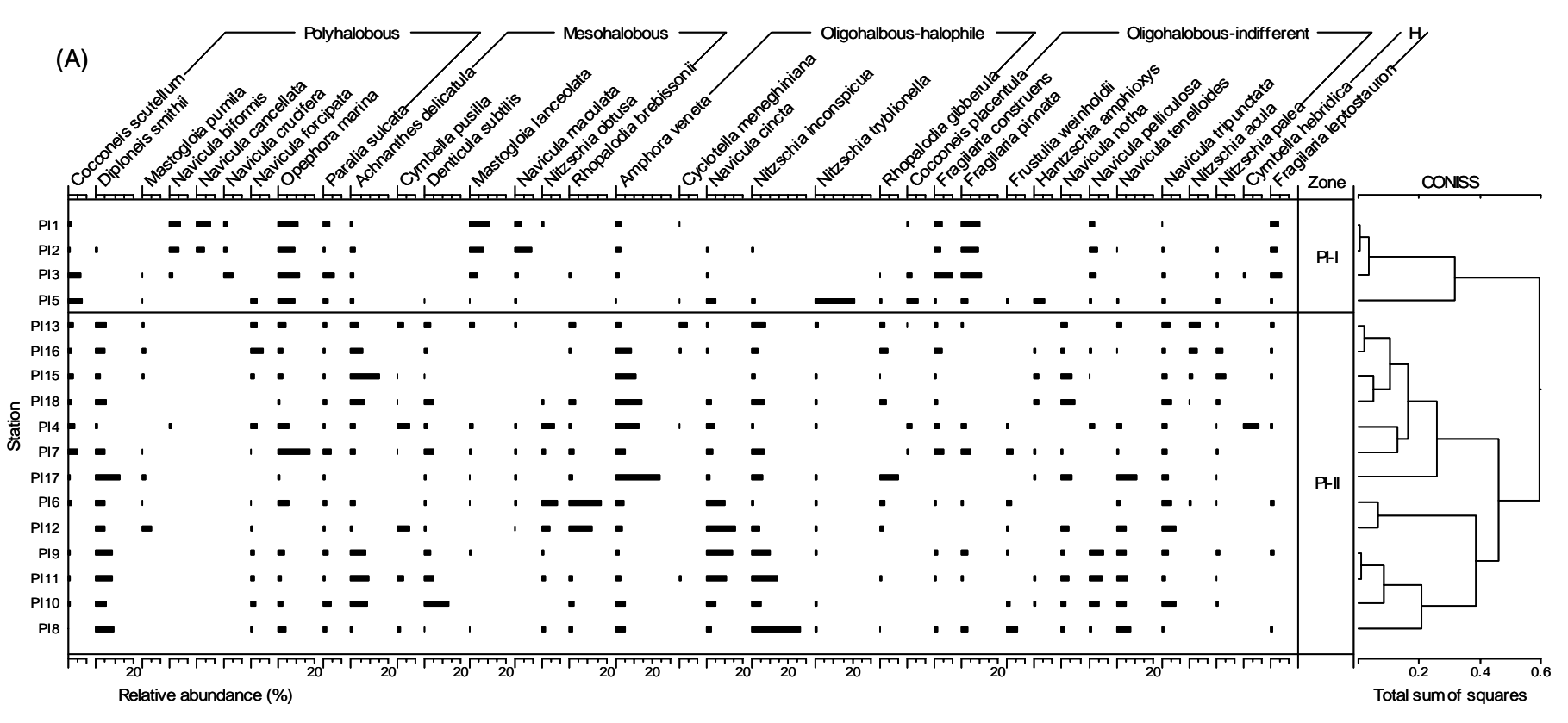

(B)

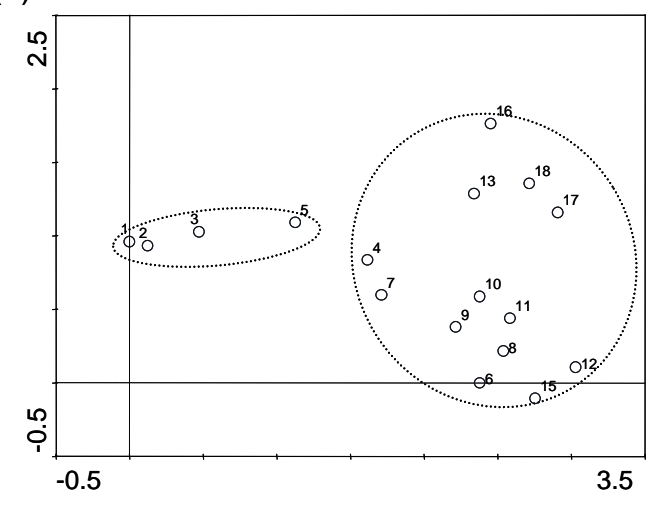

(C)

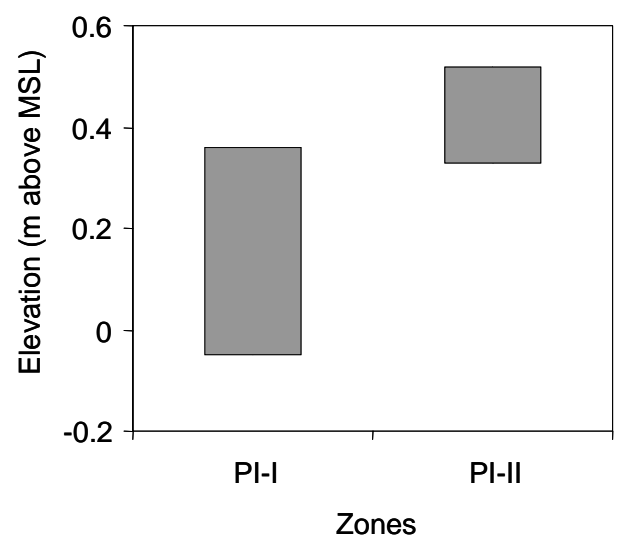

Figure 7. (A) Unconstrained cluster analysis based on unweighted Euclidean distance (species $>5 \%$ are shown) (B) detrended correspondence analysis and (C) vertical zonation of diatom assemblages (\%) from Pea Island marsh. $\mathrm{H}$ = halophobous 
(A)

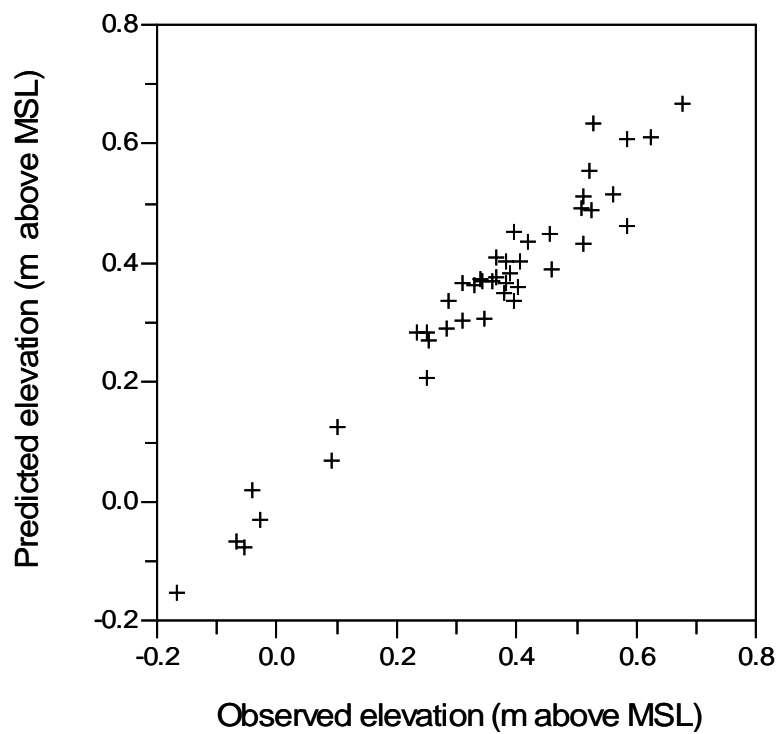

(B)

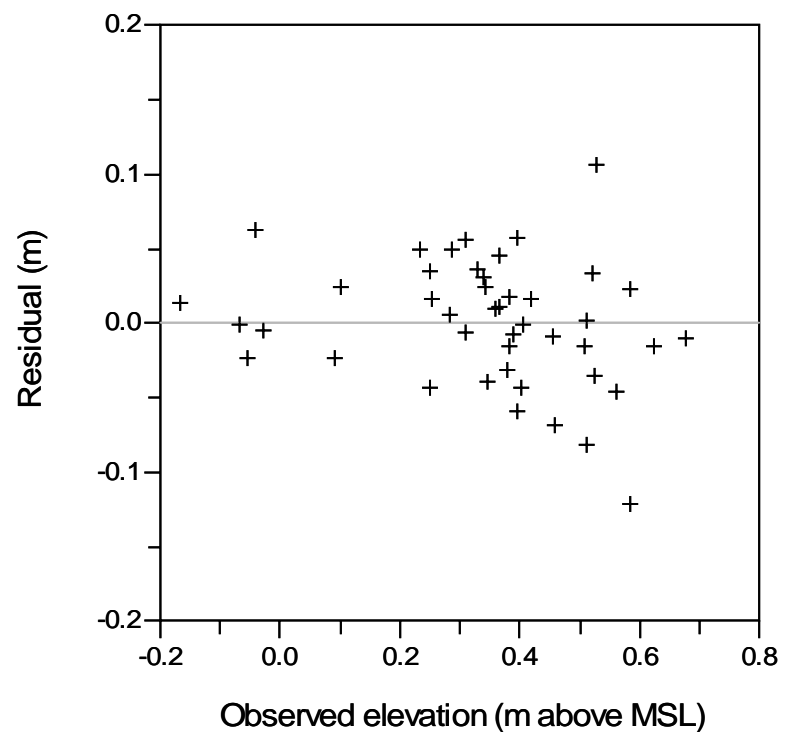

Figure 8. (A) Scatter plots and (B) residuals showing the relationship of the regression of the of observed elevations versus diatom-predicted elevations using WA-PLS from Currituck Barrier Island, Oregon Inlet and Pea Island marshes. 


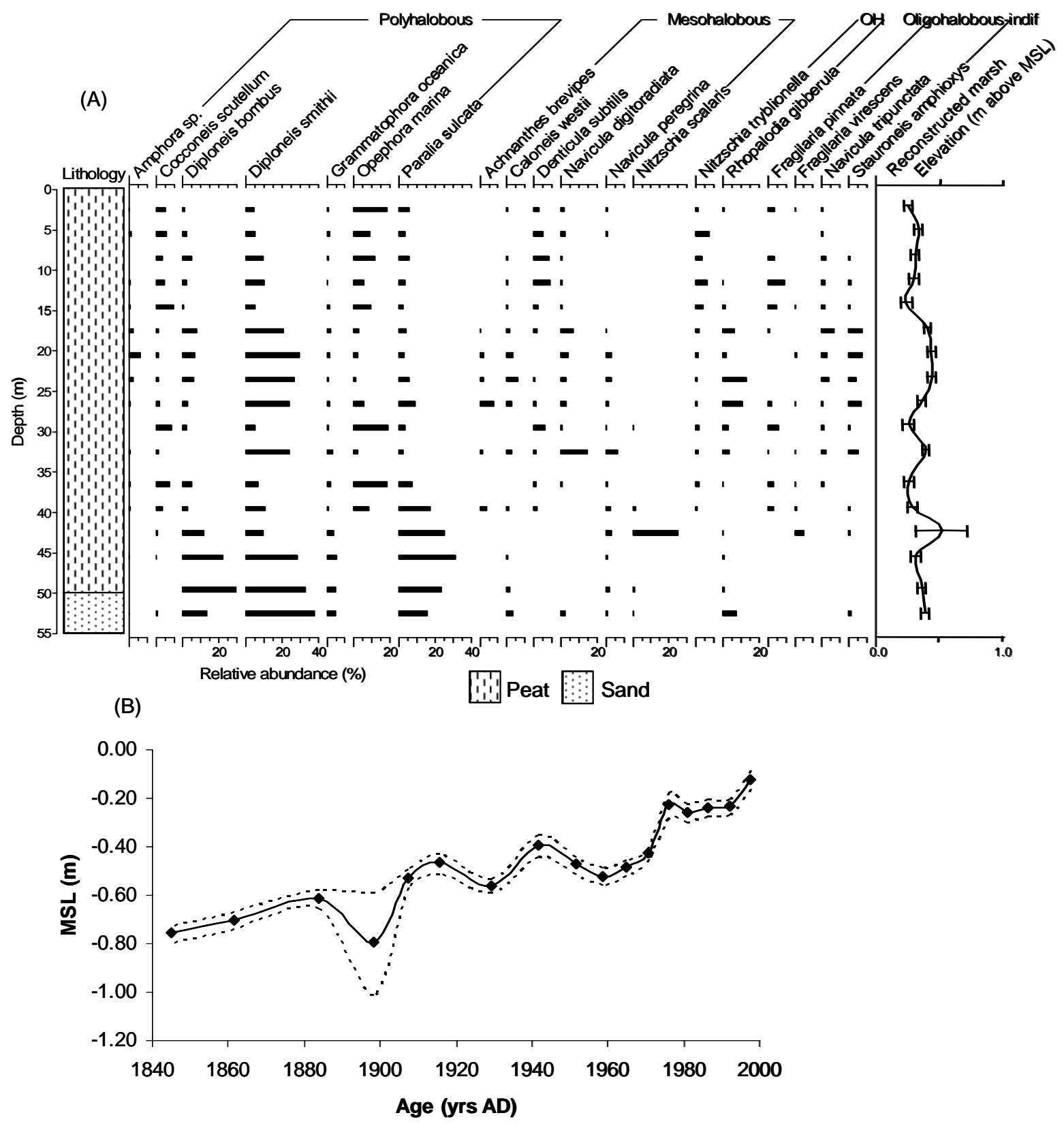

Figure 9. (A) Salvo Core SAL02S1P1 diatom diagram. Diatom abundance is calculated as a percentage of total diatom valves (species $>5 \%$ are shown). Lithology, marsh elevations predicted using WA-PLS with associated error ranges are shown. $\mathrm{OH}=$ oligohalobous-halophilus; $\mathrm{OI}=$ oligohalobous-indifferent. Surface elevation of the core is $0.14 \mathrm{~m}$ above MSL. (B) Reconstruction of Holocene mean sea-level curve for Salvo Core SAL02S1P1 using the diatom-based transfer function. 